\title{
Hiring in the Optometric Practice Trouver des employés pour son cabinet optométrique
}

\author{
by / par ALPHONSE CAREW, OD
}

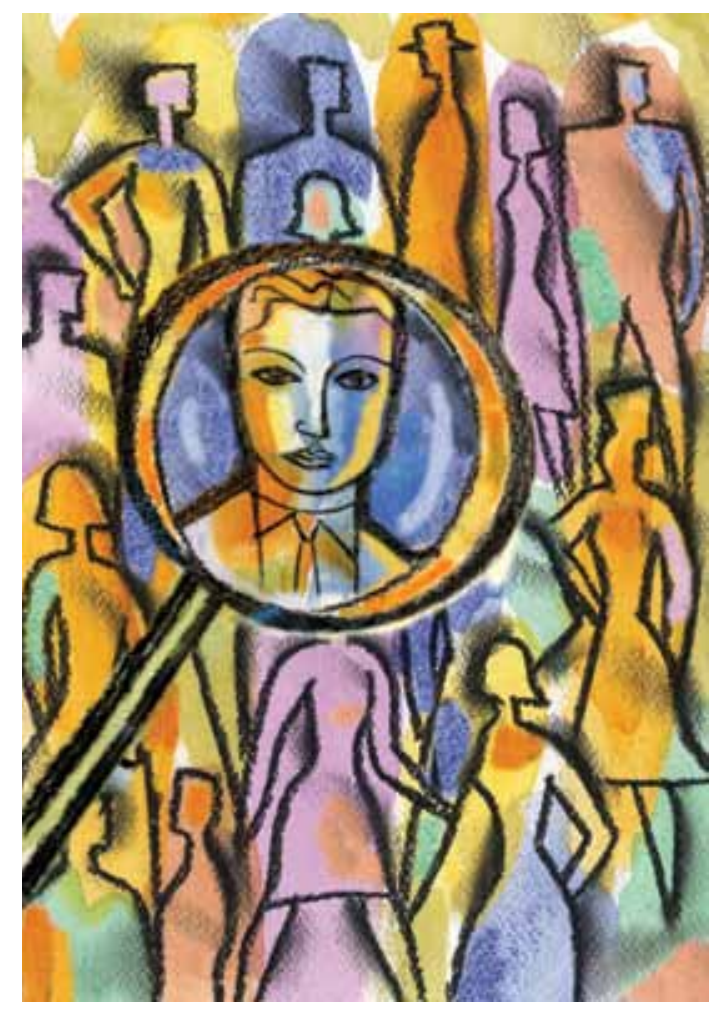

he optometric practice needs to be a truly
customer, or patient, focused organization in
order to become the practice we wish it to be.

Nothing impacts our patient's perception of our office more than their experience with your staff, for they generally spend far more time with them than they do you! It is vitally important that you attract the right kind of new hires and train these people in an efficient manner.

Because of growth, or due to someone leaving, the process starts with the search for a new person. You should seek out the newer web-based services for your posting as most people now view these as their main place to look for jobs, the newspaper ad is only useful in small markets where it still has a loyal readership. Spell out as best you can what you are looking for, provide a short job description, the general location of the practice along with the office hours and expected salary range. It's best to be as clear as possible so that those who respond will be highly matched to what you need.

Once the resumes are whittled down to a few good candidates these should be interviewed at your office, with at least two people sitting in on the interview. It's a good idea to have a staff member who will be working with the new hire as the second person. There are plenty of on-line resources that can provide questions to ask but in general you are looking for someone who is capable of learning and has a pleasant demeanour, how they answer questions is more important than their actual answer. Can they think quickly on their feet? Do they have a friendly, warm manner? It is better to hire for personality and aptitude as these people can be trained for nearly any position.

Once you have found the right person and they have accepted the position with your terms (including a three month probationary period) the training period starts. It is of the utmost importance to get this person started with the right attitude, you don't get a second chance of making that first and lasting impression. On their first day set aside 20 or 30 minutes to explain the culture, mission and values of your practice. For the rest of the day have them shadow one of your staff who is doing the job that he, or she, will be 
doing. There maybe some procedures you wish to teach to the new hire yourself, but most can be trained by an existing staff member. Make sure you choose an employee who is expert at what they do and has the desire and ability to teach someone, for not everyone is good at this.

There are also on-line resources to provide your new staff with background information on what an optometric practice does, along with the various roles inside the office. CAO has a great optometric assistance course that they offer by correspondence, we make the course mandatory for every employee once they have gone through their probationary period.

It is important to follow-up on the new hire on a regular basis. Meet with the person regularly to see how they are fitting in as well as how their training is going. I like to use a printed spreadsheet that lists the tasks that the person has to learn how to do and both the trainer and the supervising doctor has to sign off on each task once the person can demonstrate their mastery of the procedure. We have these spreadsheets for various positions in our office, once it is developed it only takes a little effort to keep it up to date. By the time of the 3 month review the candidate should have their spreadsheet tasks completed and is fitting in nicely, if there is anything lacking we will usually either extend the probationary period or decide to let the person go and start again. It's better to be sure you have the right person for the job tather than forcing the fit or making allowances.

Today's workers become terribly frustrated when they are thrown into a job with little or no training and it greatly increases the chances of them walking away from your office. It can be expensive, in both money and time, to replace these staff members so it is important to seek out the right candidate, follow-up with them regularly and train them to be experts.
I e cabinet optométrique doit véritablement être orienté vers le client ou le patient si nous voulons qu'il devienne le cabinet que nous souhaitons. Rien n'influence plus la perception que nos patients se font de notre bureau que les relations qu'ils entretiennent avec vos employés, car ils passeront habituellement beaucoup plus de temps avec eux qu'avec vous! Il est donc essentiel que vous attiriez les bons employés et que vous les formiez efficacement.

Que ce soit parce que votre cabinet a pris de l'expansion ou parce qu'un employé a quitté son emploi, le processus commence par une recherche. Pourquoi ne pas envoyer votre demande de personnel aux nouveaux services d'emploi sur Internet, que la plupart des gens aujourd'hui consultent au premier rang? Une annonce de journal n'est efficace que dans un marché restreint où le journal compte encore un lectorat fidèle. Soyez aussi précis et aussi clair que possible dans ce que vous cherchez : courte description du poste, emplacement général du cabinet, heures de travail et échelle salariale. Vous aurez ainsi plus de chance d'attirer des personnes qui correspondent exactement à vos critères.

Dès que vous aurez sélectionné les meilleurs candidats parmi les curriculum vitæ que vous aurez reçus, conviez-les à une entrevue à votre cabinet, à laquelle participera au moins une autre personne. Il serait bon que cette deuxième personne soit un membre du personnel qui travaillera avec le nouvel employé. Il y a une multitude de ressources en ligne qui peuvent vous fournir des questions à poser, mais vous cherchez en général quelqu'un capable d'apprendre et affichant une attitude plaisante. La façon de répondre est plus importante que la réponse elle-même. La personne peut-elle réfléchir rapidement par elle-même? A-t-elle une attitude amicale et chaleureuse? Il est préférable d'embaucher une personne pour sa personnalité et ses aptitudes puisque vous pourrez ensuite la former pour à peu près n'importe quel travail.

Dès que vous aurez trouvé la bonne personne et qu'elle aura accepté le poste aux conditions que vous

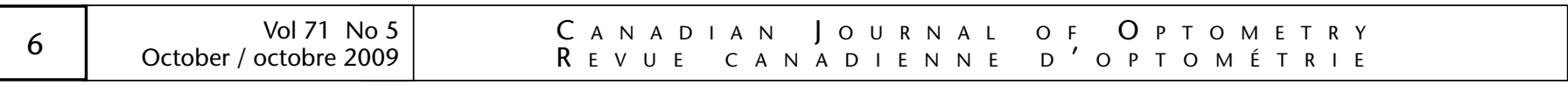


lui offrez (dont une période de stage de trois mois), la période de formation débutera. Il est de la plus haute importance que cette personne commence avec la bonne attitude, puisqu'on n'a habituellement pas une deuxième chance de faire une première impression durable. Lors de la première journée de travail, prenez une trentaine de minutes pour expliquer la culture, la mission et les valeurs de votre cabinet. Pour le reste de la journée, demandez-lui d'observer un des employés dont il fera le travail. Vous désirerez peut-être enseigner vous-même quelques procédures à cette nouvelle personne, mais la plupart peuvent être formées par un membre du personnel existant. Choisissez comme formateur un employé qui connaît à fond son travail et qui a la capacité et le désir de transmettre ses connaissances, car tous n'excellent pas à enseigner.

Vous pouvez aussi trouver en ligne, pour votre nouvel employé, des renseignements de base sur les fonctions d'un cabinet d'optométrie et sur les divers rôles qu'on y joue. L'ACO offre un excellent cours par correspondance pour les assistants optométriques. Le cours devient obligatoire pour tous les employés à la fin de leur période de stage.

Il est important de faire un suivi régulier auprès de la nouvelle personne pour voir comment elle s'intègre et assimile la formation. J'aime utiliser un docu- ment écrit qui présente, à la façon d'un chiffrier, les tâches que la personne doit apprendre. Dès qu'elle démontre sa maitrise d'une procédure, le formateur et l'optométriste signent la feuille en regard de la tâche en question. Nous disposons de feuilles de ce genre pour les postes de notre cabinet. Elles sont très faciles à tenir à jour. Au bout de la période de trois mois, le candidat devrait être confirmé dans sa maîtrise de chacune des tâches et il devrait s'être intégré parfaitement dans le cabinet. S'il reste des lacunes, nous prolongeons habituellement la période de stage ou nous donnons à la personne son congé et nous recommençons le processus d'embauche. Il est préférable d'avoir la bonne personne plutôt que d'essayer de forcer quelqu'un à s'intégrer dans un emploi ou de faire des compromis.

Aujourd'hui, il est terriblement frustrant pour un travailleur d'être catapulté dans un emploi sans aucune formation, d'autant plus que vous courez le risque qu'il quitte votre cabinet. Comme le remplacement des membres du personnel peut être un processus long et coûteux, il est important de trouver les bonnes personnes, d'assurer des suivis réguliers et de les former pour qu'elles deviennent des spécialistes dans leur travail.

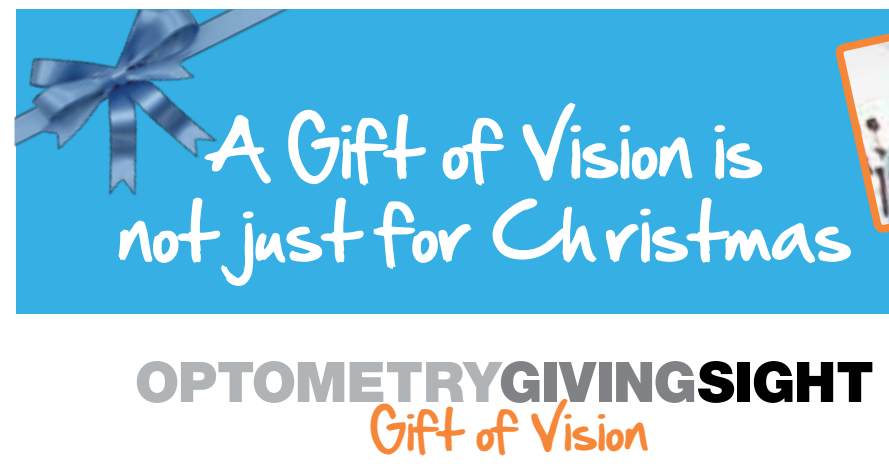

1-800-585-8265 ext. 4

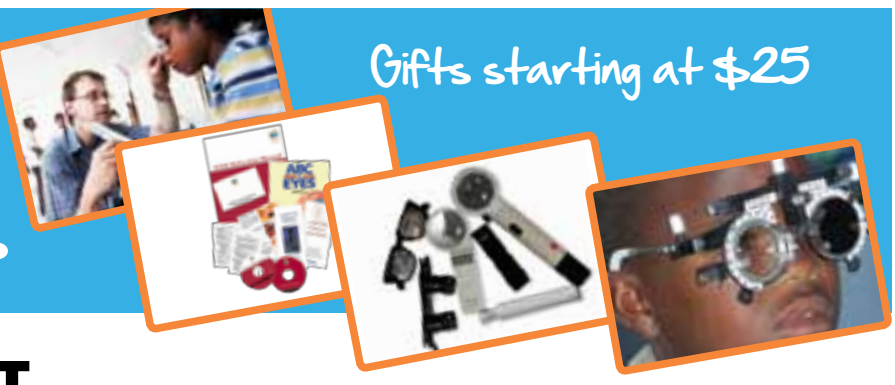

To buy a gift visit www.givingsight.org/giftofvision 